\title{
Sustainable waste processing in a grate furnace and in a fluidized bed incinerator: WtE, recycling and environmental concerns
}

\author{
I. Vermeulen ${ }^{1}$, J. Van Caneghem ${ }^{1}$, C. Block ${ }^{1,2}$, A. Van Brecht ${ }^{3}$, \\ G. Wauters ${ }^{3}$ \& C. Vandecasteele ${ }^{1}$ \\ ${ }^{1}$ Department of Chemical Engineering, University of Leuven, Belgium \\ ${ }^{2}$ Leuven Engineering College Groep T, Belgium \\ ${ }^{3}$ Indaver NV, Mechelen, Belgium
}

The Indaver integrated grate furnace, incinerating municipal solid waste (MSW) along with comparable industrial waste, is described. In the installation energy is recovered by producing steam which is delivered to other companies, or used to generate electricity. The bottom ashes are wet-washed; ferrous and non-ferrous metals and granulates are recovered. Next to the grate furnace, a fluidized bed combustor (FBC) operated by SLECO is situated. It can co-incinerate various types of industrial wastes (including ASR), RDF, waste water treatment (WWT) sludges, etc. and produces steam to generate electricity. The bottom ashes are recovered as secondary raw material. It is demonstrated that both installations have a good environmental performance and address many aspects of cleaner production. This way, both grate furnace and $\mathrm{FBC}$ may play an important role in sustainable waste management. Depending on the fractions of the energy carrier(s), the actual energy recovery varies from $41 \%$ for the grate furnace (steam + electricity) to $27 \%$ for the FBC (only electricity). The most important airborne emissions and solid residues are monitored in both installation and are discussed in detail. For all components of interest, emissions remain well below Flemish limit values. Moreover, it was shown that both installations act as a POP sink when flue gas emissions are taken into account as a POP output. From the bottom ashes of both incinerators ferrous and non-ferrous metals and granulates are recovered, representing 19.9 and $9.2 \mathrm{wt} \%$ of the original waste input of respectively the grate furnace and the $\mathrm{FBC}$. When introducing higher amounts of heavy metals into the FBC, co-incinerating ASR, the bottom ashes still fulfil Flemish requirements for use as secondary raw material.

Keywords: waste-to-energy, material recovery, ASR, MSW, RDF, heavy metals, POPS. 


\section{Introduction}

Sustainable waste management has the objective to deal with waste in an environmentally, economically and socially acceptable way. In this context, incineration of various waste types such as MSW, RDF, WWT sludge, ASR, etc. represents an important treatment option, as it enables recovery of materials and energy, while considerably reducing the amount of waste to be landfilled $[1,2]$. The relative importance of different waste treatment and disposal options can vary substantially, depending on the geographical region, as it depends strongly on the specific waste management strategy as well as the availability of space for final landfill disposal [3]. Given that Flanders is very densely populated and due to the stringent European landfill legislation, a lot of effort has been given to reduce the amount of landfilled waste [4].

Indaver is one of the largest waste management companies within the Benelux. Two important waste treatment facilities at the Indaver site, the grate furnace incineration plant and the SLECO fluidized bed combustor, are considered within the present paper. Both incinerators will first be discussed briefly. Next to this, it will be investigated to what extent these installations comply with the relevant aspects of cleaner production: energy recovery, material recovery and minimal emissions. As waste incinerators are still often considered as a source of POPs, particularly of PCDD/Fs, this aspect will be discussed in more detail. A previously proposed methodology is applied in order to find the aggregated sum of all POPs in the input and in the output of the incinerators. These weighed sums (input vs. output) are subsequently compared in order to investigate whether the considered incinerators must be seen as a POP sink or source. Moreover, the recovery of the bottom ashes is put into focus. From the bottom ashes of both incinerators ferrous metals, non-ferrous metals and granulates are recovered. It is investigated whether the leaching of the bottom ashes still complies with regulatory limitations when higher amounts of heavy metals are introduced into the FBC. It will be demonstrated that both installations combine maximum material and energy recovery with a maximum attention for environment and safety. For each considered aspect, a complete and quantitative picture will be given.

\section{Material and methods}

\subsection{Installations}

Both considered installations are located at the Indaver site, situated in an industrial zone close to Antwerp, in the vicinity of one of the most important petrochemical and chemical complexes in the world.

The grate furnace incineration plant is comprised of three grate furnace lines, with an annual capacity of roughly $40210^{3}$ ton (for the year 2010) [5]. The different components of a grate furnace line are shown in Figure 1. The waste, typically MSW or comparable industrial waste, is delivered in a secluded place (bunker). Using a crane, the waste is introduced onto the moving grate where it 
is incinerated at a minimum temperature of $850^{\circ} \mathrm{C}$. The flue gas is passed trough a boiler in order to recover its energy as superheated steam $\left(40 \mathrm{bar}, 400^{\circ} \mathrm{C}\right)$, which is partly sent to a turbine for electricity production. The flue gas treatment consists of a half wet spray dryer, injecting lime milk, followed by a baghouse filter and a wet scrubbing installation, using limestone and lime. Activated carbon is injected immediately after the spray dryer to adsorb dioxins, PAHs and volatile heavy metals such as $\mathrm{Hg}$. The resulting solid residues are denominated bottom ash, boiler ash and flue gas cleaning residue. The bottom ash is mechanically treated in order to recover metals and granulates which can be used as secondary raw material. The boiler ash and the flue gas cleaning residue are landfilled after stabilisation/solidification.

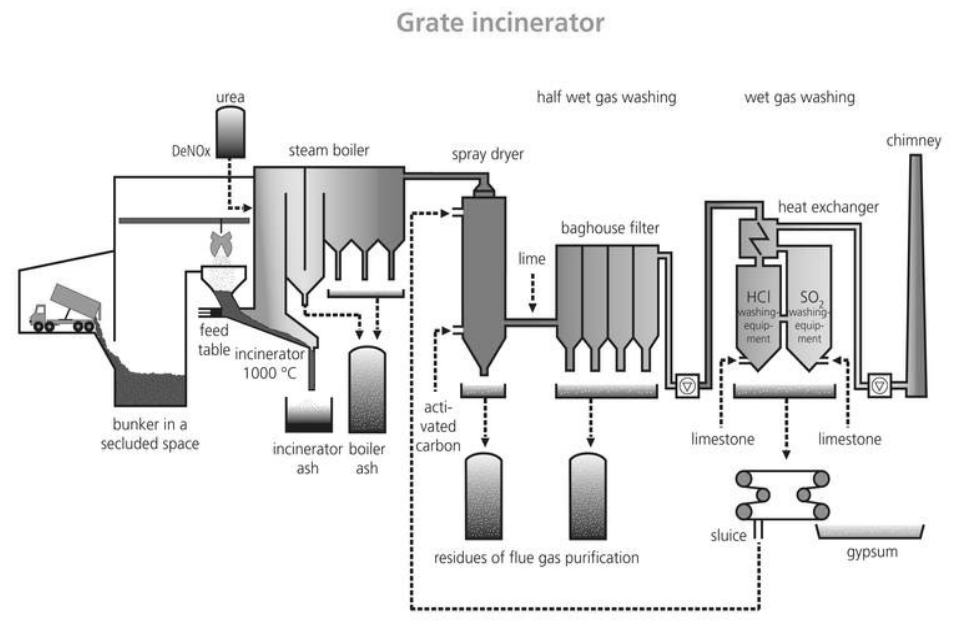

Figure 1: Schematic representation of the grate furnace at Indaver.

The SLECO fluidized bed combustor (FBC) at the Indaver site, generally coincinerates high calorific RDF with low calorific WWT sludge. This installation has an annual capacity of $50010^{3}$ ton of mixed waste (for the year 2010), making it the largest and most recent FBC for this purpose in Europe [5]. The FBC is of the ROWITEC internal rotating fluid bed type [Figure 2]. The RDF is reduced in size and after removal of ferrous metals, it is introduced in the fluidized sand bed together with the WWT sludge. During an eight day, full scale experiment in the FBC, $25 \%$ of ASR was co-incinerated with the regular waste mix [6-8]. Temperatures in the fluidized sand bed are on average $720^{\circ} \mathrm{C}$, while in the freeboard temperatures of about $920^{\circ} \mathrm{C}$ are reached. Energy from the flue gas is recovered in a vertical waste heat boiler, producing superheated steam (40bar, $400^{\circ} \mathrm{C}$ ) which is sent to a turbine for electricity production. The flue gas is first dedusted in an electrostatic precipitator (EPS) and flows subsequently through a semi-dry Circoclean reactor, a baghouse filter and a caustic sauda scrubber. A 
mixture of clay and activated carbon particles (dioxorb) is injected in the semidry reactor to ensure efficient PCDD/F removal. At the bottom of the fluidized bed, sand and ashes are removed, after which the sand is sieved of and sent back into the incinerator. The remaining residue, denominated bottom ash, is treated in a recovery plant, producing granulates which can be valorised (useful purpose). Moreover, they fulfil the product criteria according to VLAREA and can therefore be used as e.g. underlayer foundations in road constructions [9]. The other solid residues, fly \& boiler ash and flue gas cleaning residue are landfilled after respectively moistening and stabilisation/solidification.

Fluidizing bed incinerator

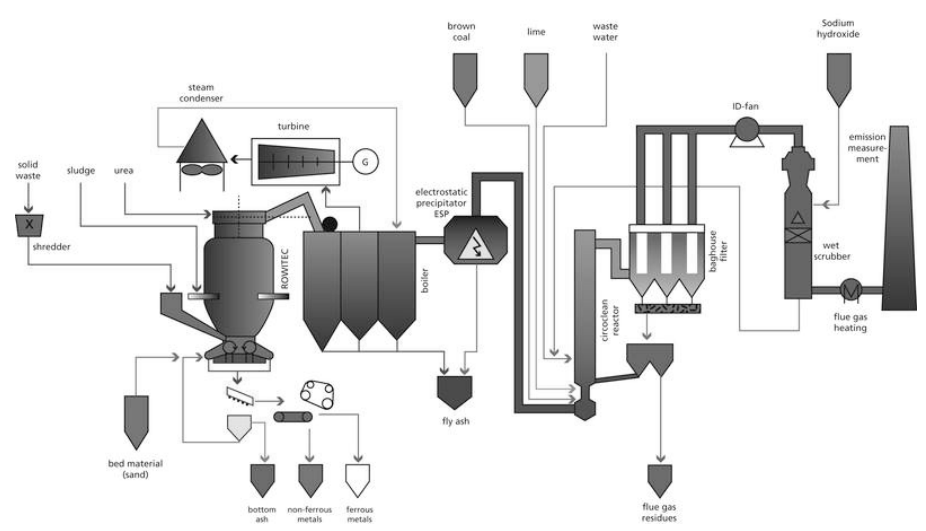

Figure 2: $\quad$ Schematic representation of the $\mathrm{FBC}$ at Indaver.

\subsection{Sampling and analysis}

Flue gases of the different incinerators are monitored, using equipment located on a measuring platform at the stack of the incinerator. Dust is monitored continuously by nefelometry; $\mathrm{HCl}, \mathrm{SO}_{2}, \mathrm{NO}_{\mathrm{x}}$ and $\mathrm{CO}$ by FT-IR in order to check their compliance with the regulatory limits. Certain pollutants, such as POPs, cannot be measured continuously; therefore the flue gas is continuously sampled every 2 weeks, using sampling equipment of the AMESA (Adsorption Method for Sampling) type, according to the EN 1948-1 standard. The POPs of interest, e.g. PCDD/Fs, dioxin-like PCBs and PAHs, are subsequently determined by a certified laboratory using GC-MS, according to the EN 1948-2 standard. This semi-continuous way of monitoring is complemented by discontinuous measurements, carried out every 6 months by similar sampling and analysis protocol. Heavy metals in the flue gas are also measured discontinuously. The flue gas is sampled using a quartz filter, analysis is subsequently conducted by using ICP-AES (CMA/2/I/B.1), except for $\mathrm{Hg}$, for which CV-AAS (CMA/2/I/B.3) is used [10]. Heavy metal content of the different solid residues is determined by using EDX-XRF. 


\section{Aspects of cleaner production and sustainable waste management}

\subsection{Energy recovery}

Energy balance of both grate furnace and fluidized bed combustor at Indaver are summarized in Table 1 . The total energy input is largely provided by the waste itself; during for instance the start-up phases, fuel oil is used as support. In the grate furnace roughly about $150 \mathrm{ton} / \mathrm{h}$ of superheated steam $\left(400^{\circ} \mathrm{C}, 40 \mathrm{bar}\right)$ is produced, corresponding to a thermal boiler yield of $77.9 \%$; the fluidized bed combustor has a thermal boiler yield of $80.0 \%$. The steam can be used in the installation itself, applied in other installation or used for the production of electricity which is subsequently fed to the electrical grid. The generated energy in the combustion process is thus made available through two energy carriers: steam and electricity. Dependent on the fractions of both carriers, the net energy recovery varies from $41 \%$ for the grate furnace (supplying both steam and electricity) to $27 \%$ for the FBC (supplying only electricity). Based on the current guidance (29.07.2010) on the Waste Framework Directive 2008/98/EC, both the grate furnace $(0.82)$ and the $\mathrm{FBC}(0.70)$ are classified as recovery (R1) [11].

Table 1: Energy balance of the grate furnace and the FBC at Indaver (data 2010), [5].

\begin{tabular}{llc}
\hline Grate furnace & GJ/year & MWh/year \\
\hline Energy content of input & $4,44010^{3}$ & \\
Energy content of steam produced & $3,45910^{3}$ & \\
Electricity produced & $52910^{3}$ & $14710^{3}$ \\
Steam supplied for application as heat & $1,30910^{3}$ & \\
\hline FBC & GJ/year & MWh/year \\
\hline Energy content of input & $4,55710^{3}$ & \\
Energy content of steam produced & $3,64510^{3}$ & \\
Electricity produced & $1,21310^{3}$ & $33710^{3}$ \\
Steam supplied for application as heat & $/$ & \\
\hline
\end{tabular}

\subsection{Emissions to air}

Table 2 gives an overview of the average yearly emission concentrations for all measured elements in both incinerators; for the full scale experiment (FBC, $50 \%$ sludge- $25 \%$ RDF-25\%ASR) the average emissions concentrations during the eight day experiment are given. It is clear that for both installations all emissions remain well below regulatory limit values, also when co-incinerating ASR in the FBC. The volatile heavy metals, $\mathrm{Hg}, \mathrm{Cd}$ and $\mathrm{Tl}$, that are monitored separately, remain up to several orders of magnitude underneath regulatory limit values.

The average annual emission concentration of $\mathrm{PCDD} / \mathrm{F}$ for 2009 , calculated on the basis of semi-continuous measurements, is $0.013 \mathrm{ngTEQ} / \mathrm{Nm}^{3}$ for the 
Table 2: Average (yearly) emissions concentration and limit values, expressed in $\mathrm{mg} / \mathrm{Nm}^{3}$ (data 2010), [5].

\begin{tabular}{lllll}
\hline Heavy metal & $\begin{array}{l}\text { Grate } \\
\text { furnace }\end{array}$ & $\begin{array}{l}\text { FBC } \\
\mathbf{3 0 \% s l u d g e -} \\
\mathbf{7 0 \% R D F}\end{array}$ & $\begin{array}{l}\text { FBC } \\
\mathbf{5 0 \% s l u d g e - ~} \\
\mathbf{2 5 \% R D F - 2 5 \% A S R}\end{array}$ & $\begin{array}{l}\text { Limit } \\
\text { value }\end{array}$ \\
\hline Dust & 0.84 & 0.6 & 0.2 & 10 \\
$\mathrm{CO}$ & 14.31 & 14.0 & 4.1 & 50 \\
$\mathrm{TOC}$ & 1.82 & 0.9 & 0.8 & 10 \\
$\mathrm{HCl}$ & 0.93 & 0.1 & 0.4 & 10 \\
$\mathrm{SO}_{2}$ & 1.55 & 1.6 & 0.0 & 50 \\
$\mathrm{NO}_{\mathrm{x}}$ & 145 & 92 & 109.8 & $200^{*}$ \\
$\mathrm{Hg}$ & $<0.0005$ & 0.013 & 0.0098 & 0.05 \\
$\mathrm{Cd}+\mathrm{Tl}$ & 0.00011 & $<0.016$ & 0.00034 & 0.05 \\
$\sum(\mathrm{Sb}, \mathrm{As}, \mathrm{Pb}, \mathrm{Cr}, \mathrm{Co}$, & 0.09 & 0.05 & 0.021 & 0.5 \\
$\mathrm{Cu}, \mathrm{Mn}, \mathrm{Ni}, \mathrm{V}, \mathrm{Sn})$ & & & & \\
\hline
\end{tabular}

"For the $\mathrm{FBC}$ the limit value for $\mathrm{NO}_{\mathrm{x}}$ is $125 \mathrm{mg} / \mathrm{Nm}^{3}$.

grate furnace and $0.008 \mathrm{ngTEQ} / \mathrm{Nm}^{3}$ for the FBC. This corresponds to a total annual emission of respectively 0.026 gTEQ and 0.019 gTEQ for the grate furnace and the FBC. This total annual emission can be considered negligible compared to the overall estimated emissions for Flanders of 42.3gTEQ in 2010 [12]. The major emission source of PCDD/F in Flanders is found to be back yard burning, accounting for up to $55 \%$ of the total emissions.

Next to this, the total amount of POPs, not just the different groups of POPs separately, in input and output of the incinerators is compared in order to investigate whether the considered installations are a POP sink or source. The authors of the present paper have previously proposed a methodology to determine the aggregated sum of all POPs by weighing the different POPs according to their minimal risk doses (MRDs) or cancer potency factors $[6,7$, 13]. For the input of the grate furnace, $\mathrm{PCDD} / \mathrm{Fs}, \mathrm{PBDD} / \mathrm{Fs}$ and polybrominated diphenylethers (PBDEs) are the main contributors. The concentration of POPs in RDF, WWT sludge and MSW is comparable, even though their specific POPfingerprint (distribution of the different POP congeners) can differ considerably $[6,7]$. The PCDD/F and PCB concentrations in MSW, RDF and WWT sludge, when expressed in $\mathrm{pgTEQ} / \mathrm{g}_{\mathrm{dw}}$, are roughly 100 times lower as the concentrations found in ASR; the PAHs concentrations are 10 times lower [6, 7]. Table 3 summarizes the ratios of the weighed POP-input over POP-output, for the different incinerators, when weighed with 1 MRDs and cancer potency factor respectively. When for the POP-output, only flue gas emissions are taken into account, the input over output ratios are in all cases significantly larger than 1 for both weighing methods, indicating that the incinerators act as a POP sink. When all outputs are considered, the weighed POP-input is comparable to the weighed POP-output for the grate furnace and the FBC (30\%sludge- $70 \% \mathrm{RDF})$. When however higher amounts of POPs are introduced into the FBC, co-incinerating ASR, the FBC acts in all cases as a weighed POP sink. This can be explained by the fact that the POPs in the waste input are almost completely destroyed during 
incineration and the formation of new POPs during the cooling of the flue gas seems to a large extent independent of the POP concentrations in the incinerated waste [7].

Table 3: $\quad$ Weighed POP input over output ratios.

\begin{tabular}{lll}
\hline & $\begin{array}{l}\text { Weighing with } \\
\text { (1/MRD) }\end{array}$ & $\begin{array}{l}\text { Weighing with } \\
\text { potency factor }\end{array}$ \\
\hline $\begin{array}{l}\text { Grate furnace } \\
\text { Total input/output(flue gas) } \\
\text { Total input/total output }\end{array}$ & $90-580$ & $6-55$ \\
\hline FBC 30\% sludge-70\%RDF & $0.3-3.2$ & $0.1-2.0$ \\
$\begin{array}{l}\text { Total input/output(flue gas) } \\
\text { Total input/total output }\end{array}$ & $120-740$ & $40-420$ \\
\hline FBC 50\% sludge-25\%RDF-25\%ASR & $0.31-0.97$ & $3.2-14$ \\
Total input/output(flue gas) & $9700-13,000$ & $1800-21,500$ \\
Total input/total output & $5.6-19$ & $9.1-127$ \\
\hline
\end{tabular}

\subsection{Material recovery}

Table 4 summarizes the weight percentages of the solid residues of both grate furnace and FBC at Indaver. The bottom ashes of the grate furnace are wetwashed prior to their recovery. During this treatment ferrous and non-ferrous metal fractions are recovered and the resulting bottom ash is split up into several granulate fractions based on their size. These granulate fractions as well as the recovered metal fractions can be valorised (useful purpose). Moreover, they fulfil the product criteria according to VLAREA and can therefore be used as e.g. underlayer foundations in road constructions [9]. Only the sludge fraction, representing $12 \mathrm{wt} \%$ of the bottom ashes of the grate furnace, has to be landfilled. The bottom ashes of the FBC are completely recovered as secondary raw material. These ashes are treated in a bottom ash recovery plant, where

Table 4: $\quad$ Mass balance of the grate furnace and the FBC at Indaver (data 2010), [5].

\begin{tabular}{ll}
\hline Grate furnace & wt\% of input \\
\hline Recovered metal fraction & 2.9 \\
Bottom ash & 22.6 \\
Boiler ash & 1.9 \\
FGC residue (including gypsum) & 2.8 \\
Total to be landfilled & $\mathbf{7 . 5}$ \\
\hline Fluidized bed combustor & $\mathbf{w t} \%$ of input \\
\hline Recovered metal fraction (scrap) & 3.2 \\
Bottom ash & 6.0 \\
Fly \& Boiler ash & 10.6 \\
FGC residue & 2.0 \\
Total to be landfilled & $\mathbf{1 2 . 6}$ \\
\hline
\end{tabular}


ferrous and non-ferrous metals are recovered and granulates are produced which can be used in road construction. The other solid residues of both installations: (fly and) boiler ash and flue gas cleaning residue are landfilled, after stabilisation/solidification. All in all only $7.5 \mathrm{wt} \%$ of the original waste input of the grate furnace and $12.6 \%$ of the original waste input of the FBC needs to be landfilled.

The bottom ashes, or at least a considerable fraction of the bottom ashes, of both installations are thus recovered as secondary raw material. Table 5 gives the leaching results of the recovered bottom ashes of both installations. For the FBC a distinction is made between the bottom ashes when incinerating the normal waste input (30\%sludge- $70 \% \mathrm{RDF}$ ) and when co-incinerating $25 \%$ of ASR. It can be seen that all leaching results are well below Flemish requirements (VLAREA limit value), even when ASR is co-incinerated in the FBC [Table 5]. In the latter case however, a slight increase in the leaching results of several heavy metals, including $\mathrm{Cu}, \mathrm{Ni}, \mathrm{Pb}$ and $\mathrm{Zn}$, is found. This increase can be attributed to ASR, containing higher concentrations of certain heavy metals than the other input streams (WWT sludge and RDF) [8].

Table 5: $\quad$ Metal leaching data from bottom ashes of grate furnace and FBC at Indaver (data 2007), [5].

\begin{tabular}{lllll}
\hline Heavy metal & $\begin{array}{l}\text { Grate } \\
\text { furnace }\end{array}$ & $\begin{array}{l}\text { FBC } \\
\text { 30\%sludge- } \\
\mathbf{7 0 \% R D F}\end{array}$ & $\begin{array}{l}\text { FBC } \\
\mathbf{5 0 \% s l u d g e - ~} \\
\mathbf{2 5 \% R D F - 2 5 \% A S R}\end{array}$ & $\begin{array}{l}\text { VLAREA } \\
\text { Limit value }\end{array}$ \\
\hline $\mathrm{As}$ & $<0.05$ & $<0.02$ & 0.08 & 0.8 \\
$\mathrm{Cd}$ & $<0.01$ & $<0.002$ & $<0.002$ & 0.03 \\
$\mathrm{Cr}$ & $<0.05$ & 0.49 & 0.01 & 0.5 \\
$\mathrm{Cu}$ & 0.29 & 0.02 & 0.17 & 0.5 \\
$\mathrm{~Pb}$ & $<0.10$ & $<0.01$ & 0.53 & 1.3 \\
$\mathrm{Ni}$ & $<0.05$ & $<0.01$ & 0.06 & 0.75 \\
$\mathrm{Zn}$ & $<0.10$ & 0.01 & 0.03 & 2.8 \\
\hline
\end{tabular}

\section{Conclusions}

It was demonstrated that both considered installations have a good environmental performance and address many aspects of cleaner production: energy recovery, material recovery and minimal emissions. This way, both grate furnace and FBC may play an important role in sustainable waste management. Both installations offer good energy recovery; depending on the energy carrier(s) this can vary from $41 \%$ for the grate furnace (supplying both steam and electricity) to $27 \%$ for the FBC (supplying only electricity). For all components of interest, emissions to air remain well below regulatory limit values. Moreover, it was shown that both installations act as a sink of POPs when only flue gas emissions are taken into account as POP output. The total amount of weighed POPs in the outputs, when considering all fractions, was found to be comparable to the total amount of weighed POPs in the input for the grate furnace and the 
regular waste input of the FBC. When introducing higher amounts of POPs in the input of the FBC, co-incinerating ASR, ratios of POP-input over -output increase so that the FBC can in all cases be considered as a POP sink.

From the bottom ashes of both incinerators ferrous metals, non-ferrous metals and granulates (subdivided based on their size) are recovered, representing 19.9 and $9.2 \mathrm{wt} \%$ of the original waste input of respectively the grate furnace and the FBC. Even when higher amounts of heavy metals are introduced into the FBC, co-incinerating ASR, leaching results of the bottom ashes still comply with regulatory limit values. All in all, only $7.5 \mathrm{wt} \%$ of the original waste input of the grate furnace and $12.6 \mathrm{wt} \%$ of the original waste input of the $\mathrm{FBC}$ needs to be landfilled.

\section{References}

[1] Vandecasteele, C., Wauters, G., Arickx, S., Jaspers, M. and Van Gerven, T., Integrated municipal solid waste treatment using a grate furnace incinerator: The Indaver case. Waste Management, 27, pp. 1366-1375, 2007.

[2] Vermeulen, I., Van Caneghem, J., Block, C., Baeyens, J., Vandecasteele, C., Automotive shredder residue (ASR): reviewing its production from endof-life vehicles (ELVs) and its recycling, energy or chemicals' valorization. Journal of Hazardous Materials, doi: 10.1016/j.jhazmat.2011.02.088.

[3] Sabbas, T., Polettini, A., Pomi, R., Astrup, T., Hjelmar, O., Mostbauer, P., Cappai, G., Magel, G., Salhofer, S., Speiser, C., Heuss-Assbichler, S., Klein, R., Lechner, P., Management of municipal solid waste incineration residues. Waste Management, 1, pp. 61-88, 2003.

[4] Background document on waste management, www.milieurapport.be

[5] Van Brecht, A. Personal communication, May 2011, Innovation Engineer, Indaver, Mechelen, Belgium.

[6] Van Caneghem, J., Block, C., Vermeulen, I., Van Brecht, A., Van Royen, P., Jaspers, M., Wauters, G., Vandecasteele, C., Mass Balance for POPs in a real scale fluidised bed combustor co-incinerating automotive shredder residue. Journal of Hazardous Materials, 181, pp. 827-835, 2010.

[7] Van Caneghem, J., Vermeulen, I., Block, C., Van Brecht, A., Van Royen, P., Jaspers, M., Wauters, G., Vandecasteele, C., Destruction and formation of PCDD/Fs in a fluidised bed combustor co-incinerating automotive shredder residue with refuse derived fuel and waste water treatment sludge. Journal of Hazardous Materials, doi: 10.1016/j.jhazmat.2011.04.064.

[8] Vermeulen, I., Block, C., Dewulf, W., Vandecasteele, C., Energetic valorisation of automotive shredder residue by co-incineration in a fluidized bed combustor. Proc. Of the $2^{\text {nd }}$ International Conference on Hazardous and Industrial Waste Management, Section A4, pp. 91-93, 2010.

[9] VLAREA, http://www.emis.vito.be/vlarea

[10] CMA, compendium for sampling and analysis in the frame of the waste and soil sanitation regulation, http://www.emis.vito.be/referentielabo-ovam 
176 Waste Management and the Environment VI

[11] European Parliament and the European Council, Directive 2008/98/EC of the European Parliament and of the Council of 19 November 2008 on waste and repealing certain Directives Text with EEA relevance, Off. J. Eur. Communities L 312, pp. 3-30, 2008.

[12] Core Set of Environmental Data MIRA-T, www.milieurapport.be

[13] Van Caneghem, J., Block, C., Van Brecht, A., Wauters, G., Vandecasteele, C., Mass Balance for POPs in hazardous and municipal waste incinerators. Chemosphere, 78, pp. 701-708, 2010. 